\title{
砂柱を含む粘土の力学的性質に関する研究 \\ THE STUDY ON CONSOLIDATION AND SHEAR STRENGTH OF COHESIVE SOIL CONTAINING SAND PILE
}

\author{
松尾稔* 一 久我昂**.前川行正*** \\ By Minoru Matsuo, Takashi Kuga and Ikumasa Maegawa
}

\section{1.はじめに}

近年軟弱地盤改良工法の一つとして, 粘土層に砂柱を 打設する工法がしばしば採用されている。これには圧密 促進の効果のみを主として期待する sand drain工法と, 粘性土層中に締まった砂柱を打設し, ある程度の圧密促 進と同時に砂柱に一種のくい効果を期待しようとする， いわゆる sand compaction pile 工法があることは周知 のとおりである。このうち前者に関しては従来から多く の研究調査がなされかなり合理的な設計が可能となって いるが, sand compaction pile を打設した複合地盤の 支持力特性に関しては研究も少なく, 未解明な点が多い といわなければならない。このよらな複合地盤の支持力 に関する解析的な取扱いには非常に困難な点が多く,ま た解析上用いなければならない多くの単純化した仮定の ためにややもすると地盤の実際的な挙動, すなわち応力 分布, 変形, 破壊現象などの実状と著しく隔たりのある 解析を行なら危険がある。しかしながらこの種の問題を 一挙に解決することはほとんど不可能であり, 実験的な 研究とあわせ逐次実状にあった解析の方向を見出してい かなければならない。この意味で, 単絍した条件下に ある砂柱を含む粘土供試体についての種々の力学的性質 を明らかにすることは非常に重要なことであり，このよ らな複合地盤の支持力特性を解明するための基礎として 必須であると考えられる。

本論文は, 砂柱を含む円筒形粘土の圧密やせん断強さ に関して三軸圧縮試験により得られた結果を示し, 種々 の考察を加えたものである。

\section{2. 実験に用いた土試料，供試体その他}

実験には表一1に示す 2 種類の粘性土を用いた。(A)， (B) 両者とも完全に脱気, 飽和したあと $0.5 \mathrm{~kg} / \mathrm{cm}^{2}$ の 鉛直荷重で再圧密した乱した粘土である。また砂柱部の
砂には豊浦標準砂を用いた。

供試体は直径 $3.5 \mathrm{~cm}$, 高さ $8 \mathrm{~cm}$ の円柱形のもので, その中心部に種々の直径および密度の砂柱を有する。粘 土の中心部に所定の径の孔をうがつには 2,3 の工夫を こらしたモールドとドリルを用い，この孔中に砂を充て んした。また試験開始に先だち砂柱は完全に水で飽和さ せた。

間げき水圧と排水量の測定は 図一1に示すような特殊 なキャップとペデスタルを通して行なった。圧密中の間 げき水圧は粘

土部で測定

し，排水は砂

柱からのみ行

なった。また

圧密終了後排

水栓は間げき

水圧測定装置

に連結され

て, せん断中

の砂柱および

粘土中の間げ

き水圧が同時

に測定できる

ようになって

いる。また供

図一1 供試体断面

試体全体とし

て側方変位を許さない圧密の場合には, 供試体の中央部, に設置された側方ひずみ計が用いられた。

\section{3. 圧密について}

\section{（1） 圧密理論の概要}

ゆるい砂柱を含む粘土の圧密, すなわち sand drain の理論と現象に関しては Barron ${ }^{1)}$ を始め Rendulic ${ }^{2)}$,

表一1 試料土の物理的性質

\begin{tabular}{|c|c|c|c|c|c|c|c|c|}
\hline \multirow{2}{*}{ 試 } & 粒 & 度 & 成 & \multirow{2}{*}{$\begin{array}{c}\text { 単 位重量 } \\
\left(\mathrm{g} / \mathrm{cm}^{3}\right)\end{array}$} & \multirow{2}{*}{ 間げき比 } & \multirow{2}{*}{$\begin{array}{c}\text { 合 水 此 } \\
(\%)\end{array}$} & \multirow{2}{*}{$\begin{array}{l}L L \\
(\%)\end{array}$} & \multirow{2}{*}{$\begin{array}{l}P L \\
(\%)\end{array}$} \\
\hline & 粘土分 (\%) & シルト分 (\%) & 砂 分 (\%) & & & & & \\
\hline A & 12.0 & 53.0 & 35.0 & 1.68 & 1.39 & 52.6 & 62.8 & 30.5 \\
\hline B & 41.5 & 54.5 & 4.0 & 1.69 & 1.38 & 52.0 & 67.5 & 43.3 \\
\hline
\end{tabular}

* 正会員 工修 京都大学助教授 工学部土木工学教室

** 正会員 工修 八幡製鉄(株)

*** 正会員 鹿島建設(株) 
Richart $^{3)}$ ，Schiffman ${ }^{4}$ その他多数の研究者や技術者に よって研究が行なわれ，またこれらの多くが Terzaghi によって確立された一次元圧密理論5) に立脚しているこ とは周知のとおりである。 sand drain を問題にする場 合, 地表面一の載荷重の条件, すなわち地表面に生ずる 沈下の状況の相違により特徴的にみて, いわゆる “free vertical strain” と “equal vertical strain” の $2 つ の$ 典型的な場合があるが，この両者の解の差はわずかであ り，実際上あまり問題にならないことが Barron や Richart の研究によって示されている ${ }^{3), 4} 。$

さてこの種の圧密問題に関して, “土塊内の圧縮ひず みはすべて鉛直方向に生じ側方に変位がない”という条 件で Terzaghi の一次元圧密理論の有するすべての仮定 を踏襲したらえでこれを拡張した圧密の微分方程式は円 筒座標表示で式 (1) のように書ける。この場合 1 本の 砂柱による 6 角形の影響圈をこれと等面積の円に置き代 えて議論が進められていることはよく知られているとこ ろである。

$$
\frac{\partial \bar{u}}{\partial t}=c_{v r}\left\{\frac{\partial^{2} u}{\partial r^{2}}+\frac{1}{r} \frac{\partial u}{\partial r}\right\}+c_{v} \frac{\partial^{2} u}{\partial z^{2}}
$$

ここに, $u$ は時間 $t$, 位置 $(r, z)$ における粘土の過剩 間げき水圧, $\bar{u}$ は位置的に平均した過剩間げき水圧, $c_{v r}, c_{v}$ はそれぞれ放射および鉛直方向の水の流れによる 圧密係数である。

鉛直方向の水の流れが無視できる場合には式 (1) の 右辺第 2 項がなくなってつぎのよ5になる。

$$
\frac{\partial \bar{u}}{\partial t}=c_{v r}\left\{\frac{\partial^{2} u}{\partial r^{2}}+\frac{1}{r} \frac{\partial u}{\partial r}\right\}
$$

“No smear and No Well Resistance” の場合に関 して Barron はつぎの境界条件,

(i ) $t=0$ において初期間げき水圧 $u_{0}$ は土塊全体に ついて等分布する, すなわち $u=u_{0}$

(ii) $t>0$ において砂柱の外周面 (半径 $r_{s}$ ) で $u=0$

(iii) $t>0$ において影響圈の外周面 (半径 $r_{e}$ ) で水 の流れがない，すなわち $\partial u / \partial r=0$

のもとで式 (2) を解き,つぎの解を得だ。

$$
u=\frac{4 \bar{u}}{d_{e}{ }^{2} F(n)}\left[r_{e}^{2} \log \varepsilon\left(\frac{r}{r_{s}}\right)-\frac{r^{2}-r_{s}^{2}}{2}\right]
$$

ここに,

$$
\left.\begin{array}{l}
\bar{u}=u_{0} \varepsilon^{\lambda} \\
\lambda=\frac{-8 T_{h}}{F(n)} \\
F(n)=\frac{n^{2}}{n^{2}-1} \log \varepsilon(n)-\frac{3 n^{2}-1}{4 n^{2}}
\end{array}\right\}
$$

であり, $\varepsilon$ は自然対数の底, $T_{h}$ は時間係数, $d_{e}$ は影響 圏の直径, $d_{s}$ は砂柱の直径, $n$ は $d_{e}$ の $d_{s}$ に対する 比である。

(2) 実験結果と考察
実験には多孔板付きのアクリル製キャップを用いたの で沈下の条件はすべて “equal vertical strain”の状態 である。表一1 の試料 (A)（以下試料 (A) を用いた試 験を単に (A) と略称する) に関しては砂柱直径（㛜密 にはドリルの直径) $d_{s}$ が $1.24 \mathrm{~cm}$ の供試体について側 圧，砂柱密度などを変えた等方圧密試験を行なった。ま た試料 (B) (以下試料 (B) を用いた試験を単に (B) と略称する) に関しては $d_{s}=0.7,1.0,1.5 \mathrm{~cm}$ の 3 種 類の供試体について多くの等方圧密試験と側方変位のな い圧密試験（以下 $K_{0}$-test と書く）を実施した。 $K_{0}$-test では鉛直圧力を終始一定に保ち, 側方変位が生じないよ らに側圧を減少させていった。

図一2，3 は（B）に関して供試体上面の粘土部で測 定した間げき水圧を時間に対して描いた一例である。 図一2 は等方圧密, 図一3 は $K_{0}$-test の結果であり, 両 図には参考のため砂柱を有しない粘土単独供試体の結果 も併記してある。これらの図をみると当然の帰結として 砂柱径 $d_{s}$ が大であるほど圧密促進の効果は著しく, 全 般に粘土単独供試体の場合にくらべて約 10 倍の速さで 過剩間げき水圧が消散している。図中の点線は, 実験曲

\section{図一2 圧密一時間曲線（等方圧密）}

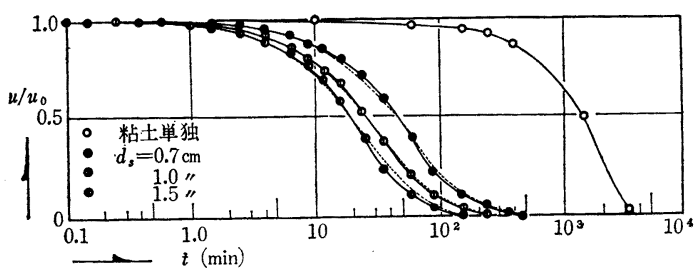

図一3 圧密一時間曲線 $\left(K_{0}\right.$-test)

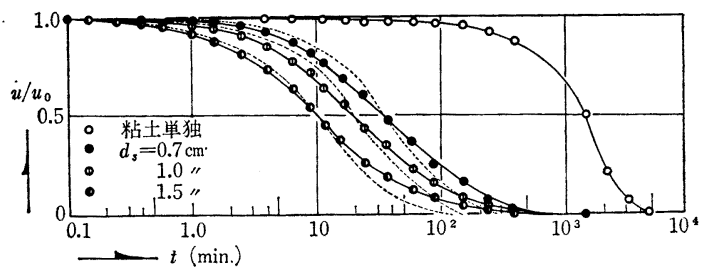

図-4 圧密係数の経時変化

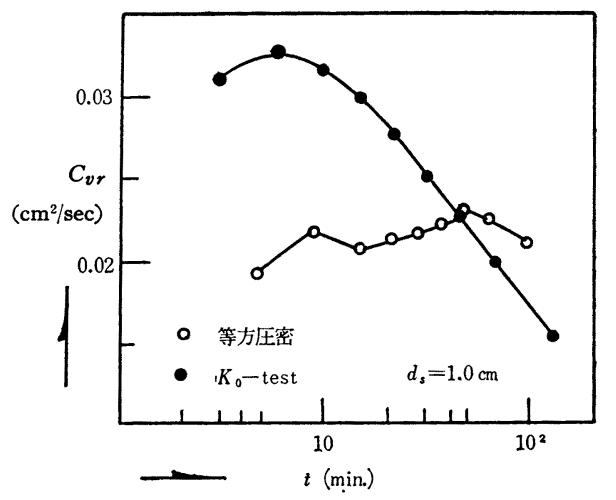


線における圧密度 $50 \%$ 時の圧密係数を用いて Barron の式 (4) により計算した理論曲線である。理論曲線は 等方圧密の場合に関して特によい一致を示しているが， $K_{0}$-test では圧密曲線の初期と終期でやや実験曲線より 逸脱している。これは主として実際の圧密過程中に生ず る圧密係数の経時変化の大小に起因していると考えられ る。試みに図一2,3 における $d_{s}=1.0 \mathrm{~cm}$ の実験曲線 汇関して Barron 式の時間係数を用いて圧密係数を逆算 した結果が 図一4である。この図によると等方圧密の場 合には $c_{v r}$ の経時変化はほとんど無視できるほど小さい のに対し， $K_{0}$-test の場合にはその変化はかなり大きく， 圧密初期における值は終期における值の約 3 倍程度とな っている。

周知のように Barron の一連の式の誘導には“排水に よる圧縮ひずみは鉛直方向にのみ生じ，側方に変位がな い”といら基本仮定が用いられている。したがってこの 意味では Barron 式による曲線は $K_{0}$-test の結果により よい一致を示すべきであると考えられるが，反面“側方 変位がない”とする仮定の裏には当然“外圧の異方性”, すなわち土塊内において時間とともに変化する “主応力 差の発生”といら事実が存在するはずである。しかし Barron は (Terzaghi の一次元圧密理論に関しても同じ であるが）この点に関して何ら言及せず，したがって式 の中に主応力差によって生ずるダイレイタンシーの効果 を入れていない。ところが実際には側方変位のない状態 においては特に圧密終期にダイレイタンシー効果が顕著 になって圧密の終了を遅らせるからこれが結果的に Barron の式を用いるかぎり計算上必然的に $c_{v r}$ の減少 といら形になってあらわれてくるものと考えられる。こ こに Barron 式の有する 1 つの問題点があり, 側方変位 がない条件での式であるにもかかわらず “c $c_{v r}$ 一定”の 仮定を含むことから，結果的に実際上 “ $c_{v r}$ が一定に近 い”ことが支配的要素になり，図一2 のような場合によ りよい一致を示すことになる。以上のことから透水係数 の時間的変化を考虑に入れて誘導されている Schiffman の式)のほうがより撖密で一般性があるが，彼も外圧の 異方性といら観点から圧密係数の時間的変化を考慮した のではないから $K_{0}$-test の結果の説明には適当でない。 しかし実際問題としては $c_{v r}$ の推定にはいる誤差やその 他種々の単純でない条件を考えると，図一2，3 からも わかるように実用上は Barron の式で十分であろう。な お図は省略してあるが，(A) に関して行なわれた等方 圧密試験に扔いても実験曲線は圧密度 $50 \%$ 時の $c_{v r}$ を 用いて計算した Barron 式の結果と非常によい一致を示 した。

さて図一2，3 を比較してみると，その間げき水圧の 経時変化に大差はないが, 一方の曲線を単に平行移動し ただけでは他方の曲線に重ならないことは明らかであ
り，等方圧密にくらべて $K_{0}$-test では圧密初期において 間げき水圧が早く消散し，反対に圧密終期において遅れ ている。これは主としてつぎの原因に起因している。す なわち $K_{0}$-test では，圧密の初期には側圧の減少にとも なう平均圧力の減少が間げき水圧減少に大きく寄与する のに対し, 圧密の後期には次第に増加する主応力差のた めに発生する付加的間げき水圧が量的にみて支配的にな ってくるためであると考えられる。これは沖積粘土の圧 密に関してすでに赤井によって指摘されている事実 ${ }^{6}$ と 同傾向である。

つぎに体積変化についてみてみる。排水量自体および これを元の全体積で除した体積ひずみは砂柱径の小なる ほど，すなわち粘土部分の体積が大であるほど大きくな るが，各時間の体積ひずみを圧密終了時の全体積ひずみ で除した值の経時変化を図示するとたとえば図一5, 6 の ようになる。これらの図は粘土中の間げき水圧に関する

\section{図一5 体掼ひずみの経時变化（等方圧密）}

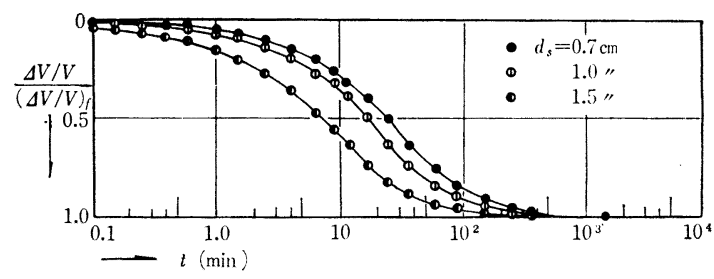

図一6 体積ひずみの経時変化 $\left(\boldsymbol{K}_{0}\right.$-test $)$

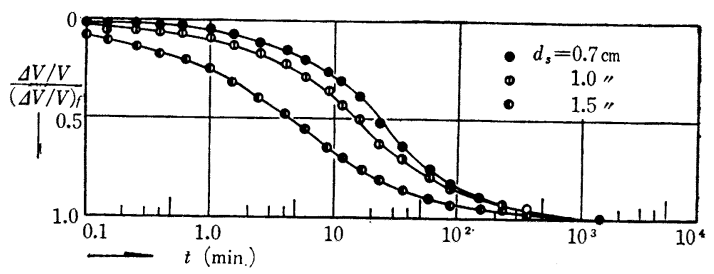

図一2，3 と類似であるが，この両者を比較すれば体積 ひずみの変化過程が間げき水圧の消散過程よりも時間的 に少し先行することがわかる。これは体積変化と間げき 水圧の減少, すなわち有效応力の増大との間に理論どお りにはいかない時間遅れのあることを示している。体積 ひずみが平均有効応力 $\sigma_{m}{ }^{\prime}$ と密接な関係を有することは よく知られているが，等方圧密と $K_{0}$-test の場合に関し て同一 $\sigma_{m}{ }^{\prime}$ に対する体積ひずみを比較すると，砂柱径の 大小にかかわらず $K_{0}$-test のほうが全般に大きい。図一7 は一例として圧密開始時の等方周圧が $5 \mathrm{~kg} / \mathrm{cm}^{2}$ の場合 を図示したものである。正規圧密粘土に関して同様の事 実はすでに赤井によって示され，この両者の相違は $K_{0}-$ test におけるダイレイタンシー効果に依存すると説明さ れている6)。今回のようなかなり密度の高い砂柱を含む 正規圧密状態の粘士供試体の場合は, 主応力差は砂柱部 と粘土部において互いに逆のダイレイタンシー効果をも 
图一7体掼ひずみと平均有効応力の関係

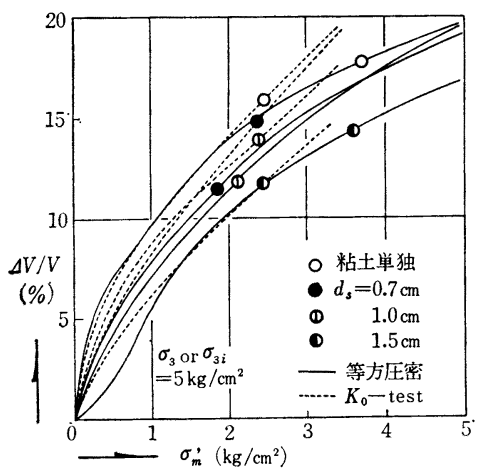

図-8 鉛直ひずみと砂柱径の関係

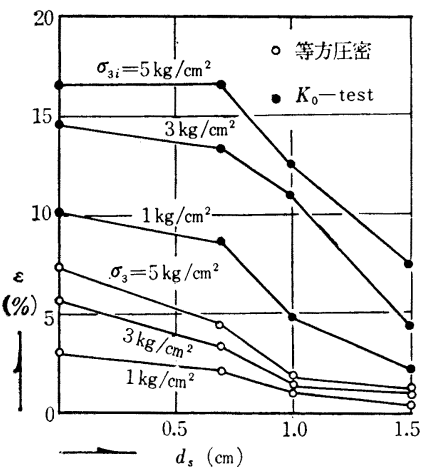

たらす。した がってこのよ うな異方圧力 下にある複合 土の全体とし ての体積変化 は砂の密度と 粘土の応力履 歷や強さ, あ るいは外圧の 大きさなどに 支配され，一 般に非常に複雑で あって現段階では 一般性のある定量 的結果を示唆する ことは不可能であ る。

図一8 は砂柱径 を変化させた場合 の圧密終了時の沈 下量を鉛直方向の ひずみで表示した もので, 圧密開始 時の側圧をパラメーターにして描いたものである。等方 圧密と $K_{0}$-test の結果を比較すると, 図一7に示したよ らに全体としての体積変化にはあまり相違がないにもか かわらず， $K_{0}$-test における鉛直ひずみは等方圧密の場 合の約 2 3 倍の大きさに達している。これは $K_{0}$-test では側方の変位が拘束されていることからその体積変化 がすべて鉛直方向の沈下量に移化される当然の帰結であ る。またこの図をみると砂柱を含む複合土供試体の沈下 量は, 粘土単独供試体の沈下量に比較して一般にかなり 小さくなることが明らかである。そしてこの程度は砂柱 径が大であるほど大きく, 特に $d_{s}=1.0 \mathrm{~cm}(n=3.5)$ 以 上でその傾向が顕著である。このことは粘性土中に適当 な径の砂柱を打設すること により沈下量をかなり大幅 に減少させらることを示す 重要な事実であるが, 同時 に砂柱打設による沈下量の 低減と圧密促進による粘土 の強さ増大の期待は相反す る現象の期待であることに 注意すべきであり, 複合地 盤の設計にはいずれの効果 をどの程度期待するかが重 要問題であることはいうま
でもない。さてこのように砂柱を含むことによる沈下量 の減少は主として鉛直圧力の砂柱への集中に起因するも のと考えられる。これは “equal vertical strain”の条 件下に扔ける砂柱部と粘土部の圧縮特性の相違に原因す る結果であり, ばらついてはいるが圧密終了時の粘土部 分の含水比を圧密終了時の供試体全体としての平均有効 応力 $\sigma_{m}{ }^{\prime}$ に対して描いた例である 図一9 も上記の事実 の存在を支持している。なおこの種の砂柱による沈下減 少の事実は茨木によっても報告されている7”。

鉛直圧力が砂柱へどの程度集中するか，すなわち砂柱 部と粘土部の荷重分担比がどの程度になるかということ は複合地盤の設計上非常に重要な問題である。実際現象 はそのときどきの条件によって非常に複雑なものになる に違いないが，つぎのような単純化によりごく大ざっぱ な推定が可能であろう。すなわち砂柱部, 粘土部ともに その圧縮ひずみは鉛直方向にのみ生ずるものと仮定する と, 砂柱部および粘土部の最終沈下量 $S_{s}, S_{c}$ はつぎの. ように書いて大過ないであろら。

$$
\begin{aligned}
& S_{s}=H_{0} \frac{C_{c s}}{1+e_{0 s}} \log \frac{\sigma_{0 s}+\sigma_{s}}{\sigma_{0 s}} \\
& S_{c}=H_{0} \frac{C_{c c}}{1+e_{0 c}} \log \frac{\sigma_{0 c}+\sigma_{c}}{\sigma_{0 c}}
\end{aligned}
$$

ここに添字 $s$ は砂を, また $c$ は粘土を表わし, $C_{c}$ は圧 縮指数, $\sigma_{0}$ は先行荷重, $\sigma_{s, c}$ は砂柱部あるいは粘土部に 実際に作用する鉛直圧力であり， $H_{0}$ は鉛直方向の層の 厚さである。一方影響圈全体に関する平均鉛直圧力を $\sigma$ とすると次式が成立する。

$$
d_{e}{ }^{2} \sigma=d_{s}{ }^{2} \sigma_{s}+\left(d_{e}{ }^{2}-d_{s}{ }^{2}\right) \sigma_{c}
$$

いま

$$
\begin{aligned}
& \frac{d_{e}}{d_{s}}=n \\
& \frac{\sigma_{s}}{\sigma_{c}}=N
\end{aligned}
$$

とおくと, 式 (6), (7) から $\sigma_{s}, \sigma_{c}$ は結局つぎのよう に書くことができる。

$$
\begin{aligned}
\sigma_{s} & =\frac{N n^{2}}{N+n^{2}-1} \sigma \\
\sigma_{c} & =\frac{n^{2}}{N+n^{2}-1} \sigma
\end{aligned}
$$

式（8）を式（5）に用い，“equal vertical strain” 条件下にある場合を考えて $S_{s}=S_{c}$ と置くと，

$$
\begin{aligned}
& \frac{C_{c c}}{1+e_{0 c}} \log \left(1+\frac{n^{2}}{N+n^{2}-1} \frac{\sigma}{\sigma_{0 c}}\right) \\
& -\frac{C_{c s}}{1+e_{0 s}} \log \left(1+\frac{N n^{2}}{N+n^{2}-1} \frac{\sigma}{\sigma_{0 r}}\right)=0
\end{aligned}
$$

式 (9) 中 $N$ 以外の各值を推定することができれば, この式を用いて概略の $N$ 值を知ることができる。しか しここで特に注意しなければならないのは，実際には圧 密の進行にともない $N$ 值は変化すると考えるのが自然 
であり，また鉛直荷重を受けた砂柱あるいは粘土部は以 上の仮定のように一次元的には圧縮されずに，ある程度 の側方変位をともならといらことである。したがって式 (9) はあくまで $N$ 值の既值を知る一つの手段にすぎ ない。このことは $\sigma_{0 s}, C_{c s}$ の推定の際の問題点を考元 ても当然のことといえる。すなわち式 (9) による計算 で問題となるのは $\sigma_{0 s}, C_{c s}$ の推定の困難さである。砂 の一次元圧縮の場合間げき比 $e$ と鉛直圧力 $\sigma$ の関係は 初期間げき比や応力履歷, さらに締固めの手段などによ って大幅に異なり，一般に $\sigma_{0 s}, C_{c s}$ を一義的に決定す ることがむずかしい。 $C_{c s}$ に関しては, 初期条件により $e \sim \sigma$ 関係が異なり, また半対数紙上で直線から多少逸 脱しても $C_{c s}$ におよぼす効果はそれほど大でなく，実 質増分荷重の範囲を極端に誤まらないかぎり式 (9) に よる粗雑さ程度の計算には実質上あまり問題はない。し かし一方 $\sigma_{0 s}$ の推定は一般にかなり困難である。ある初 期間げき比を有する砂をある大きさの鉛直荷重によって 静的に圧縮したのちに, さらに所定の鉛直増分荷重が付 加されるような場合には，これに対応するような静的一 次元圧縮試験による $e \sim \log \sigma$ 曲線を利用することであ まり問題はないが，一般の sand compaction pile 工法 のように砂柱を振動などによって締固める場合には，付 加される静的鉛直載荷の以前にどの程度の載荷効果を受 けたか，すなわち $\sigma_{0 s}$ としてどのような值をとるかによ って式 (9) による計算結果の良否が左右されることに 注意しておかなければならない。

なお $K_{0}$-test の場合, 圧密の進行にともなう側圧の減 少過程の一例をあげると 図一10 のようである。この図 の縦軸には側圧と鉛直圧力の比 $\left(K=\sigma_{3} / \sigma_{1}\right)$ がとってあ る。この図からわかるように $K$ の減少は $d_{s}$ が大であ るほど早く,また $K$ は 1 から次第に減少して圧密終了 時には 0.5 に漸近している。粘土単独供試体に関して は, 圧密終了時に $K$ が大体 0.5 となることがすでに明 らかにされているが6)，砂柱を含む複合土も同傾向を示 すことは興味媣い。

\section{図-10 $K=\sigma_{8} / \sigma_{1}$ の経時変化}

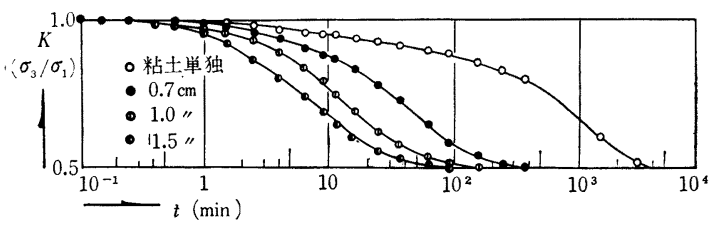

\section{4. せん断強さについて}

砂柱を含む粘土供試体のせん断強さは, 複合地盤の支 持力に関する設計上最も重要かつ基本的な問題である が, 茨木 ${ }^{778}$ による実験的研究以外あまり発表されたも のもなく, 現在まで未解明な点が非常に多い。本章では 始めにこの種の問題に関する二次元弾塑性論に基づく理

論的な取扱いの可能性と理論の構成上の問題点や限界に 触れ，その後に三軸圧縮試験の結果とこれに対する種々 の考察を示す。

\section{（1）二次元弾塑性問題としての取扱いの可能性につ いて}

砂柱を含む粘土供試体あるいはこのような単位の集合 である複合地盤の破壊には特徴的にみてつぎのような場 合が考えられる。すなわち（1）砂柱打設中または打設 直後, 砂柱をとおして粘土部分に伝達される横圧力が大 であるため粘土に破壊が生ずる場合。この場合を非常に 単純理想化して考えると, 図一11 に示すある平面内の 応力に関して $\sigma_{\theta}$ あるいは $\sigma_{r}$ がそれぞれ最大または最 小主応力に, $\sigma_{z}$ が中間主応力に近い状態になって破壊 が生ずるものと考えられ

る。(2) 砂柱の打設が 終りその後盛土その他の 大きな載荷重を受けた場 合や, ある荷重で圧密さ れたあとにさらに大きな 荷重が付加された場 合 に, 非排水に近い状態で 粘土部そして砂柱を含む 全体が破壊に至ったり， また地下水位の高い複合 地盤の切土のように地下 水位の復元とともに安全 率が低下してついに破壊

\section{図一11理想化された応力状態} に至るような場合。この ときはおそらく図一11 の $\sigma_{\boldsymbol{z}}$ が最大あるいは最小主応力 に近いものとなるであろう。(3) 粘土部分の 圧密が進 み, 粘土部分に作用する鉛直圧力に比較して砂柱に著し い圧力集中を生じ, 砂柱自体, そしてついに砂柱を含む 全体が破壊する場合。砂柱がいったん破壊しても，これ が周囲の粘土に与える変形量が粘土を破壊に至らしめる ほど大でない場合は, 砂は再圧縮を受け, したがって載 荷重は再び等分布し, 粘土部の沈下 $\rightarrow$ 砂柱への圧力集 中 $\rightarrow$ 粘土部への横圧力増大をくり返し, 最終的に落着く か, または破壊することになるであろう。このような破 壊が生ずるとすればその主応力間の大小関係は（1）の 場合と同様になるであろう。

さてこの種の問題に比較的類似した問題として, 歷史 的に古くから研究されてきたものに二次元弾塑性問題と しての内外圧を受ける厚肉中空円筒の問題がある。たと えば金属に関しては $\mathrm{Hill}^{9)}$, Steel ${ }^{10)}$, Hodge ${ }^{11)}$ などの 理論的, 実験的研究があり, 土に関してもやはり二次元 弾塑性問題としての取扱いにおいて掘削孔周辺の応力状 態を決定しょうとした Terzaghi の研究 ${ }^{12), 13)}$ や中空円筒 形粘土の応力状態の解析に関する Fröhlich の研究 ${ }^{14)} な$ 
どがある。さらに $\left.\mathrm{Wu}^{15}\right)$ らは主として中間主応力が粘 土のせん断強さにおよぼす影響を調べるために，内外周 に等分布荷重を受ける中空円筒形粘土の力学的性質を理 論的, 実験的に研究している。

内外周にそれぞれ等分布圧力 $p_{i}, p_{0}$ を受ける中空円 筒形弾性体が平面ひずみ問題として取扱える場合には， 内圧力の増大とともに塑性領域は円筒内壁より内部へと 同心円的に拡大していく。そして弾塑性境界の半径を $t$ とすると, 円筒の任意水平断面上の中心から半径 $r$ にお ける弾性領域内の中心方向およびこれに直角方向の応力 $\sigma_{r}, \sigma_{\theta}$ は Lamé の解の拡張としてつぎのように書ける ことはよく知られている(16),17)。すなわち $t \leq r \leq b$ に おいて,

$$
\begin{aligned}
& \sigma_{r}=-\frac{t^{2} b^{2}\left(p_{t}-p_{0}\right)}{\left(b^{2}-t^{2}\right) r^{2}}+\frac{\left(p_{t} t^{2}-p_{0} b^{2}\right)}{\left(b^{2}-t^{2}\right)} \\
& \sigma_{\theta}=\frac{t^{2} b^{2}\left(p_{t}-p_{0}\right)}{\left(b^{2}-t^{2}\right) r^{2}}-\frac{\left(p_{t} t^{2}-p_{0} b^{2}\right)}{\left(b^{2}-t^{2}\right)}
\end{aligned}
$$

ここに, $p_{t}$ は弾塑性境界上に働く方射方向の圧力, $a, b$ はそれぞれ円筒の内径と外径であり, 上式は弾性学の慣 習にしたがい圧縮を負として表示してある。

一方 $\sigma_{z}$ が中間主応力に近い状態にあり，破壊が Mohr-Coulomb の破壊規準にしたがうとすれば塑性領 域では,

$$
\left.\begin{array}{l}
\sigma_{\theta}=\sigma_{r} N_{\varphi}-2 c \sqrt{N_{\varphi}} \\
N_{\varphi}=\tan ^{2}\left(\frac{\pi}{4}+\frac{\varphi}{2}\right)
\end{array}\right\}
$$

をつりあい式

$$
\frac{\partial \sigma_{r}}{\partial r}+\frac{\left(\sigma_{r}-\sigma_{\theta}\right)}{r}=0
$$

に用いて解くとつぎのようになる。すなわち $a \leq r \leq t$ において,

$$
\begin{aligned}
\sigma_{r}= & -\left\{p_{i}+\frac{2 c \sqrt{N_{\varphi}}}{\left(N_{\varphi}-1\right)}\right\}\left(\frac{r}{a}\right)^{\left(N_{\varphi}-1\right)}+\frac{2 c \sqrt{N_{\varphi}}}{\left(N_{\varphi}-1\right)} \\
\sigma_{\theta}= & -\left\{N_{\varphi} p_{i}+\frac{2 c \sqrt{N_{\varphi}}}{\left(N_{\varphi}-1\right)}\right\}\left(\frac{r}{a}\right)^{\left(N_{\varphi}-1\right)} \\
& +\frac{2 c \sqrt{N_{\varphi}}}{\left(N_{\varphi}-1\right)}
\end{aligned}
$$

ここに， $c, \varphi$ はいわゆる粘着力と内部摩摖角であり, 式 (13) はすでに Wu によっても求められている15)。 ところで $r=t$ に扔いて式 (10) と（13）に扔りる $\sigma_{r}$ は 連続しなければならないから,この条件により $p_{t}$ はつ ぎのように求められる。

$$
p_{t}=\left\{p_{i}+\frac{2 c \sqrt{N_{\varphi}}}{\left(N_{\varphi}-1\right)}\right\}\left(\frac{t}{a}\right)^{\left(N_{\varphi}-1\right)}+\frac{2 c \sqrt{N_{\varphi}}}{\left(N_{\varphi}-1\right)}
$$

式 (10)，(13)，(14）より， $p_{i}, p_{0}$ が与えられたとき の理想的な平面ひずみ状態における弾性および塑性領域
の応力が一応決定されるわけであるが, 逆にいってこれ らの式では塑性領域を $r=t$ まで進めるのに必要な $p_{i}$, $p_{0}$ を求めることはできない。工学的な意味でわれわれ が知りたいのは $t$ がいかなる大きさになったときに巨視 的な意味での複合土の破壊と考えればよいのか，またそ の $t$ まで塑性領域が拡大されるための $p_{i}, p_{0}$ の大きさ はどの程度か, さらに $p_{i}, p_{0}$ と表面載荷重との関係は どのようにして決定すればよいかなどである。たとえば $t=b$ になったときに複合土の破壊と考え式 (13) で $r=t, \sigma_{r}=-p_{0}$ として $p_{i}$ と $p_{0}$ の関係をきめ, さらに 砂柱表面の鉛直圧力と $p_{i}$ との間にある関係を仮定する とか，あるいはまた円筒全体がまだ完全に弾性状態にあ るとして求められる円筒外周の側方変位がないとして $p_{i}$ と $p_{0}$ の関係をきめ, やはり砂柱表面の鉛直圧力と $p_{i}$ の間にある関係を仮定したうえで $t=a$ ですでに全体 の破壊と考え, 結局砂柱への鉛直圧力がいくらになった ときに破壊であるというようにするのが一つの手段とし て考えられる。しかし中空円筒形粘土の内外周に水圧な どの $z$ 方向に理想的な等分布圧力を与えらる小さな三軸 供試体ならともかく, 砂柱を含む粘土供試体, 特に外圧 と比較して土の自重が無視できない現地の複合地盤の場 合, 平面ひずみ問題と考えるのはあまりにも現状と離れ すぎ,さらに不確かな砂柱への鉛直圧力の集中に関する 仮定, 砂柱をとおして粘土に伝わる $p_{i}$ の大きさや分布 の推定の困難さを考えるとあまりにも問題点の多すぎる ことがわかる。

さて始めに述べた（2）のような破壊の場合，すなわ ち粘土部の $\sigma_{z}$ が一般に非常に大きくなって破壊に至る 場合にはこのような方法での理論的な取扱いはさらに困 難さを増し, 上述した実状との隔たりもますます大きく なる。この場合にはもはやいかに都合よく解釈しても平 面ひずみ状態になるとは考えられないが，仮りにそのよ らに仮定したとしても応力間の関係式はつりあい式のほ かに破壊条件式,

$$
\sigma_{z}=\sigma_{r} N_{\varphi}-2 c \sqrt{N_{\varphi}}
$$

だけであり, 明らかに始めから条件式が一つ不足であ る。ここで Wu のように plastic potential の理論を導 入したり ${ }^{15)}$, あるいはまた Haythornthwaite が置いた ${ }^{18)}$ ように,

$$
\left.\begin{array}{l}
\sigma_{\theta}=k \sigma_{z}+(1-k) \sigma_{r} \\
0 \leq k \leq 1
\end{array}\right\}
$$

として $\sigma_{z}, \sigma_{\theta}, \sigma_{r}$ について解き， $k$ を適当に仮定する方 法などが考えられるが，たとえば式 (12)，(15)，(16) を解くと $p_{i}$ と砂柱表面の応力との関係など前述した問 題点があるのはもとより, 平面ひずみ状態の仮定の当然 の帰結として $\sigma_{\boldsymbol{z}}, \sigma_{\theta}, \sigma_{\boldsymbol{r}}$ は $z$ に無関係となる。前述し たよらに理想的な条件下にある小さな三軸用粘土供試体 ならともかく, 複合土供試体やさらに現地複合地盤にい 


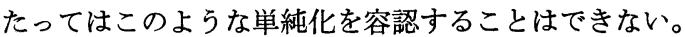

以上の考察より砂柱を含む粘土のせん断強さに関して は, 二次元弾塑性問題としての厚肉中空円筒の考え方は 参考にはなりえても，準用あるいは拡張使用することに ははなはだ問題が多いといわなければならない。現時点 においてはまず現象を正しく把握していくこと，すなわ ち実験的研究の積み重ねがきわめて重要であると考えら れる。

\section{(2) 実験結果亡考察}

実施したせん断試験は, 主として非圧密非排水せん断 試験と圧密非排水せん断試験の 2 種類であり, 両者とも ひずみ制御でせん断した。

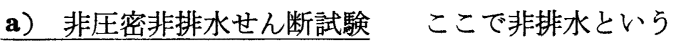
のは“砂柱部と粘土部で多少の水の移動はあるかも知れ ないが，全体として外部への排水はない”という意味で ある。せん断速さは（A）の場合 $1.33 \% / \mathrm{min}$ ，（B）の 場合が $1 \% / \mathrm{min}$ である。また砂柱の密度は大，中，小 の 3 種類に変えたが, 密度大というのは最初ドリルでう がった孔の体積が砂充てん時にも変化がないとしたと き，密度が $1.7 \mathrm{~g} / \mathrm{cm}^{3}$ になるように砂をつめたことを意 味する。同様に密度中, 小はそれぞれ $r=1.6,1.5 \mathrm{~g} / \mathrm{cm}^{3}$ であるが, 砂充てん時にドリル孔はある程度押し拡げら れるであろらから, 実際の密度は上述したものより小さ いと考えられる。

(B) に関して側圧 $\sigma_{3}=3 \mathrm{~kg} / \mathrm{cm}^{2}$ の場合について, 主 応力差 $\left(\sigma_{1}-\sigma_{3}\right)$ と鉛直方向の軸ひずみ $\varepsilon$ との関係を砂 柱径 $d_{s}$ をパラメーターにして描いた一例が 図一12 であ る。この図には粘土単独供試体, すなわち $d_{s}=0$ の場 合の $\left(\sigma_{1}-\sigma_{3}\right) \sim \varepsilon$ 関係も併記してあ るが，この図から 同一側圧下におい てせん断強さにお よぼす砂柱の効果 は明らかである。 $d_{s}=1.5 \mathrm{~cm} \quad(n=$ 2.33）の場合には この効果が特に顕 著に表われてお り, 最大主応力差
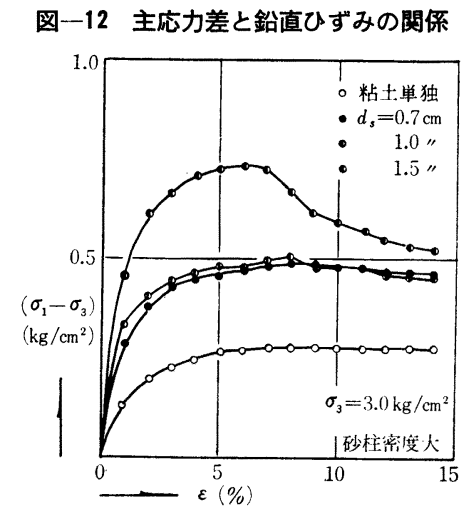
は粘土単独の場合の約 2.8 倍となっている。またこのと きの $\left(\sigma_{1}-\sigma_{3}\right) \sim \varepsilon$ 関係が比較的よく締まった砂の一般的 な曲線形に類似していることには注目しておかなければ ならない。以上のことは $\sigma_{3}$ の大きさにかかわらず同傾 向であった。

図一13 は $\sigma_{3}$ をパラメーターにして描いた同様の図で ある。実線はやはり (B) に関するもので $d_{s}=1.0 \mathrm{~cm}$ の場合の試験結果であり, 点線は $d_{s}=1.24 \mathrm{~cm}$ で (A)

図一13 主応力差と鉛直ひずみの関係

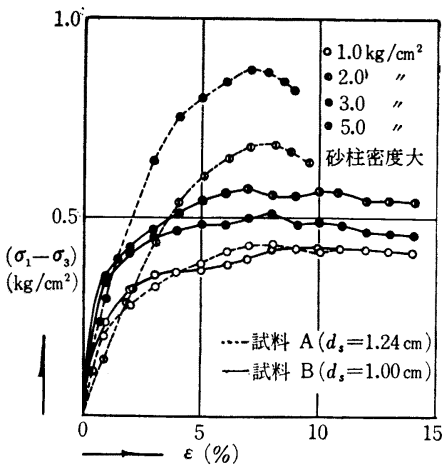

に関するものである。砂柱および粘土部はともに完全に 水で飽和されているから，一見せん断強さは $\sigma_{3}$ の変化 にあまり関係がないように想像されるが，実際には図に みられるようにかなり相違し, $\sigma_{3}$ が大になるほど $\left(\sigma_{1}-\sigma_{3}\right)$ は大きくなっている。これは主として砂柱部のせん断に ともなら砂のダイレイタンシーの性質に起因している。 すなわち側圧が大になるほど粘土部をとおして発揮され る砂の膨張を拘束する効果が大となり, 結果的に砂のせ ん断の過程をとおして砂中の有効応力が増大するものと 考えるのが自然である。またこの図によると $\sigma_{3}=1 \mathrm{~kg} /$ $\mathrm{cm}^{2}$ の場合には明確な peak point が生ぜず粘土に類似 の曲線形を示しているが， $\sigma_{3}$ が大きくなるにしたがって

\section{図一14 主応力差と鉛直ひずみの䦕係}

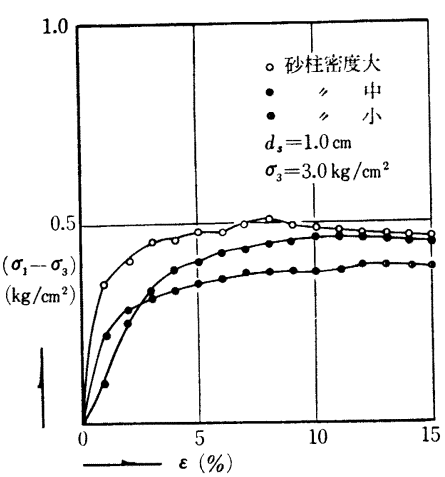

peak point があら われ, $\left(\sigma_{1}-\sigma_{3}\right)_{\max }$ になる は小さく なってくる。そし て特に(A)の場合 に顕著なように, その曲線形が砂柱 の影響を大きく受 けていることがわ かる。以上のこと は砂柱径が大であ るほど著しかっ

図一15 充てん砂重兵と最大 主応力差の関係

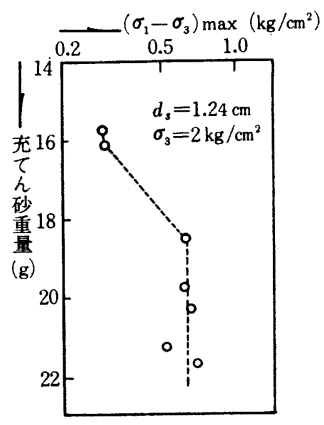

た。なお図一14 は(B)に 関して砂柱密度を変えた場 合の試験結果であり，砂柱 密度の増大につれてせん断 強さが大きくなることがわ かる。しかし $(\mathrm{A})$ に関する 図一15に示すように, 充て ん砂の重量を増していくと ある限度までは砂柱自体の 密度が上昇しこれにつれて 強さも増加するが，ある限 界以上になると締固め圧力 
が粘土の粘性による抵抗力よりも大となり $\left(\sigma_{1}-\sigma_{3}\right)_{\max }$ にほとんど変化がないことに注目しなければならない。 このことは実際の砂柱打設に際しても, その締固めエネ ルギーと粘土の強さその他の関係において充てん砂の密 度にはおのずから限界のあることを示している。

さて複合地盤の設計に際しては砂柱を含む粘土の変形 や強さ特性, 設計のための $c, \varphi$ などの係数の推定が直 接重要な問題となるわけであるが，この場合実際的には 粘土単独あるいは砂単独の場合の諸性質からこれらが複 合された複合土の諸性質を推測したいという要望が生ず るのは当然である。たとえば砂および粘土がそれぞれ単 独別個に発揮しうる最大の強さが, 複合土となった場合 も同時に発揮されるとして複合地盤のせん断強さを推定 する仕方は最も安易であるが, 締固めた砂と柔らかい粘 土の応力と変位関係の相違を思い起こせばこのような評 価の仕方に納得できないことは明らかである。そこで砂 および粘土の単独別個の応力〜ひずみ関係から，これら による複合土の強さや変形の性質を推定する一つの手段 としてつぎのような計算を行なった。すなわち砂および 粘土単独供試体に関する三軸圧縮試験より得られたそれ ぞれの $\left(\sigma_{1}-\sigma_{3}\right) \sim \varepsilon$ 関係において, 同一の $\varepsilon$ に対する主 応力差を $\left(\sigma_{1}-\sigma_{3}\right)_{s},\left(\sigma_{1}-\sigma_{3}\right)_{c}$ とし, 一方全水平横断面 積が $A_{t}$ である複合土供試体の砂柱部と粘土部の断面積 を $A_{s}, A_{c}$ としたとき, やはり同一の $\varepsilon$ に対するこの 複合土供試体の主応力差 $\left(\sigma_{1}-\sigma_{3}\right)_{s+c}$ が次式で近似でき るものとする。

$$
\left(\sigma_{1}-\sigma_{3}\right)_{s+c}=\frac{a\left(\sigma_{1}-\sigma_{3}\right)_{s} A_{s}+\left(\sigma_{1}-\sigma_{3}\right)_{c} A_{c}}{A_{t}}
$$

式 (17) は一見すればわかるように, 砂および粘土に ついての別個の応力〜ひずみ関係をもとに，同一ひずみ 量に対するそれぞれの主応力差を複合土における砂柱部 と粘土部の実質断面積に比例して配分し，これらを加算 したものをもってそのひずみ量に対する複合土の主応力 差と考えることを意味している（Leonards は粘性土の 核を有するアースダムのすべりに関して, 異なった材料 内を横切るすべり面の長さを考慮に入れて同様の計算を 行なうことをすすめている $\left.{ }^{19)}\right)$ 。式中 $a$ は係数であり， 砂に関してのみこのような係数を付加したのは, 複合土 において特に砂柱の強さはこれをとりまく粘土の強さに も支配されるから，常に粘土と同一の比重で効果をおよ ぼすとは考えにくいからである。

（A）に関して実験値と比較した計算結果の例を示そ う。図一16 は今回用いた豊浦標準砂と粘土の三軸圧縮 試験結果である。砂に関しては, 粘土中における砂柱の 条件と少し異なるであろらがまったく同一の状態を再現 することは不可能であるので排水試験と非排水試験を行 なった。両者に大差はなかったが，どちらかといえば排

\section{図一16 主応力差と鉛直ひずみの関係}

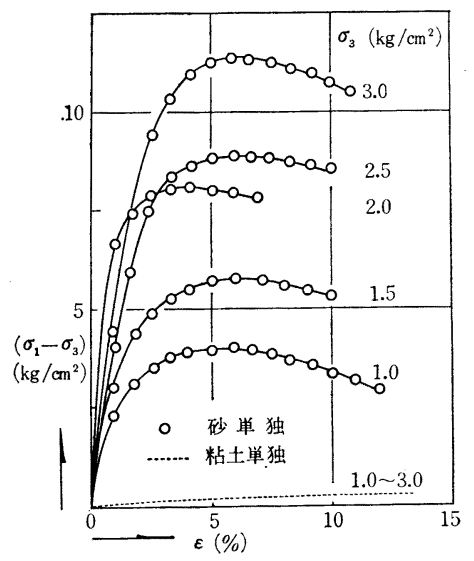

図一17 主応力差と鉛直ひずみの関係

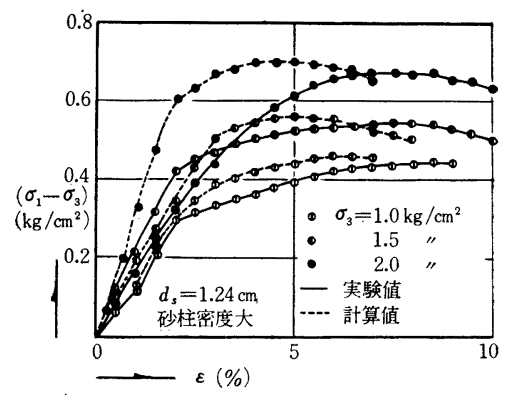

水状態の方が粘土中の砂柱の状態に近いと考えられたの でこの結果を用いることにした。図一16 には排水試験 の結果が描かれている。さて式 (17) の $a$ を $1 / 2$ とし 図一16 に基づいて計算した結果を実験曲線と比較する と図一17 のようになった。この図からわかるように計 算曲線は実験曲線とよく一致している。このことは注目 すべきであり, 砂および粘土単独別個の曲線から複合土 の応力〜ひずみ関係を推定する一つの手段であると考え られるが, 実際には砂のダイレイタンシーの性質により 誘発されるせん断中の粘土の圧密効果や鉛直圧力の砂柱 への集中効果など複合土特有の複雑な現象をともなって いるはずであるから, 式 (17) のように主として面積の みに基づく算定法は厳密な意味では妥当性に欠ける面も ある。また係数 $a$ のつ意味については今後の研究で調 べたい。なお式 (17) においては, 砂柱部と粘土部のせ ん断面が基準面から同一傾斜していることを暗默のうち に了解しているわけであるが(三軸の場合はこれでよ い), 複合地盤のすべり計算などで式 (17) と同様の考え 方を用いる場合には, せん断面の方向の相違を考慮して 面積を考える必要が生ずるであろう。

表一2 に各試験における $\left(\sigma_{1}-\sigma_{3}\right)_{\max }$, これらに基ゔ いて描いた Mohr の破壞円の包らく線が $\tau$ 軸を切る切 片 $(c)$ と傾斜角 $(\varphi)$ などを一括表示した。なお表中 A-1 から B-12 までは砂柱密度大, B-13〜B-15 が中, 
表一2 非圧密非排水せん断試験結果

\begin{tabular}{|c|c|c|c|c|c|}
\hline 試験番号 & $\begin{array}{c}d_{s} \\
(\mathrm{~cm})\end{array}$ & $\begin{array}{c}\sigma_{3} \\
\left(\mathrm{~kg} / \mathrm{cm}^{2}\right) \\
\end{array}$ & $\left|\begin{array}{c}\left(\sigma_{1}-\sigma_{3}\right)_{\max } \\
\left(\mathrm{kg} / \mathrm{cm}^{2}\right)\end{array}\right|$ & $\begin{array}{c}c \\
\left(\mathrm{~kg} / \mathrm{cm}^{2}\right)\end{array}$ & $\begin{array}{c}\phi \\
\left({ }^{\circ}\right)\end{array}$ \\
\hline A-1 5 & 0 & $\begin{array}{l}1.0,1.5 \\
2.0,2.5 \\
3.0\end{array}$ & 0.24 & 0.12 & 0 \\
\hline A-6 & 1.24 & 1.0 & 0.43 & \multirow{4}{*}{0.10} & \multirow{4}{*}{6} \\
\hline A-7 & 1.24 & 1.5 & 0.55 & & \\
\hline A-8 & 1.24 & 2.0 & 0.69 & & \\
\hline A-9 & 1.24 & 3.0 & 0.88 & & \\
\hline B-1 3 & 0 & $\begin{array}{l}1.0,3.0 \\
5.0\end{array}$ & 0.29 & 0.15 & 0 \\
\hline B-4 & 0.7 & 1.0 & 0.44 & \multirow{3}{*}{0.15} & \multirow{3}{*}{2} \\
\hline B-5 & 0.7 & 3.0 & 0.51 & & \\
\hline B-6 & 0.7 & 5.0 & 0.51 & & \\
\hline B-7 & 1.0 & 1.0 & 0.43 & \multirow{3}{*}{0.15} & \multirow{3}{*}{2} \\
\hline B-8 & 1.0 & 3.0 & 0.51 & & \\
\hline B-9 & 1.0 & 5.0 & 0.57 & & \\
\hline B-10 & 1.5 & 1.0 & 0.48 & \multirow{3}{*}{0.15} & \multirow{3}{*}{4} \\
\hline B-11 & 1.5 & 3.0 & 0.74 & & \\
\hline B-12 & 1.5 & 5.0 & 0.78 & & \\
\hline B-13 & 1.0 & 1.0 & 0.42 & \multirow{3}{*}{0.20} & \multirow{3}{*}{1} \\
\hline B-14 & 1.0 & 3.0 & 0.47 & & \\
\hline B-15 & 1.0 & 5.0 & 0.53 & & \\
\hline B-16 & 1.0 & 1.0 & 0.31 & \multirow{3}{*}{0.13} & \multirow{3}{*}{1} \\
\hline B-17 & 1.0 & 3.0 & 0.39 & & \\
\hline B-18 & 1.0 & 5.0 & 0.45 & & \\
\hline
\end{tabular}

B-16〜B-18 が砂柱密度小の結果である。

b) 圧密非排水せん断試験 （A）の場合は等方圧 密のあと $0.083 \% / \mathrm{min}$ のせん断速さで, また (B)につ いては等方圧密あるいは $K_{0}$-test のあと $0.06 \% / \mathrm{min}$ の速さでせん断した。せん断中おおむね砂柱部と粘土部 の間げき水圧を測定したが，特に（B）においては間げ き水圧測定の精度をあげるためにせん断開始前に約 0.5 $\mathrm{kg} / \mathrm{cm}^{2}$ の back pressure を導入した。

まず応力〜ひずみ関係をみてみる。図一18 は (A)に 関するもので, 図中点線は粘土単独の, また実線は $d_{s}=1.24 \mathrm{~cm}$ (圧密開始時の值, 以下同じように初期值

\section{図一18 主応力差と鉛直ひずみの関係}

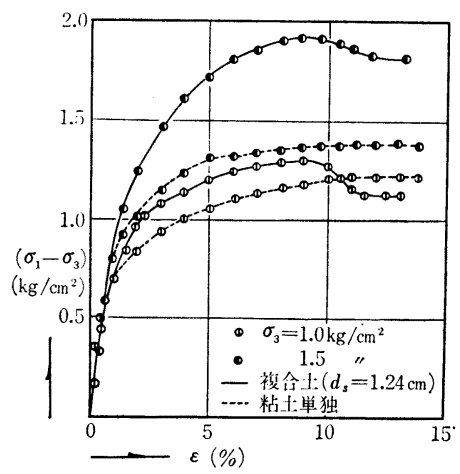

が図一19 である。図中複合 土に関するものは，その $\left(\sigma_{1}-\sigma_{3}\right)_{\max }$ を“粘土部分の 含水比”に対してプロットし てある。この図によると複合 土の場合も粘土単独の場合と 同様に $w \sim \log \left(\sigma_{1}-\sigma_{3}\right)_{\max }$ 関係に直線性のあることがわ かる。またこの図において特 に注意しなければならないの は, 両者がほぼ平行でしかも 複合土に関するものが粘土単
図一19 含水比と最大主応 力差の関係

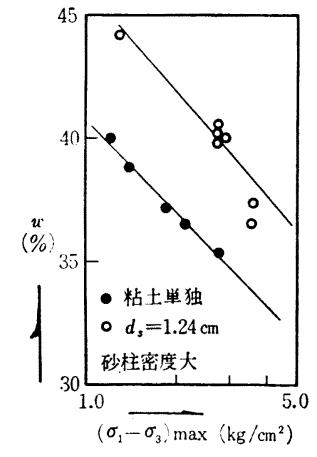
独の場合の右側に位置していることである。このことは 砂柱の効果が同一含水比に対する両者の横軸の差として あらわれていることを示している。いいかえると粘性土 に関して同程度の圧密が完了したあとの強さは，適当な 径の砂柱を含む場合が粘土単独にくらべてかなり大きく なることを示唆している。

図一20，21 は (B) に関して $d_{s}$ をパラメーターにし て描いた図で, 前者は $\sigma_{3}=3 \mathrm{~kg} / \mathrm{cm}^{2}$ で等方圧密したあと の応力〜ひずみ関係を, また後者は圧密開始時の側圧 $\sigma_{3 i}=3 \mathrm{~kg} / \mathrm{cm}^{2}$ で $K_{0}$-test したあとのものである。図一20 をみると $d_{s}$ の増大につれて主応力差は大きくなり, 曲 線形も砂のそれに近づいてくることがわかる。 $d_{s}=0.7$ $\mathrm{cm}$ の場合は粘土単独の場合に比較してそれほど顕著な

図一20 主応力差と鉛直ひずみの関係（等方圧密後）

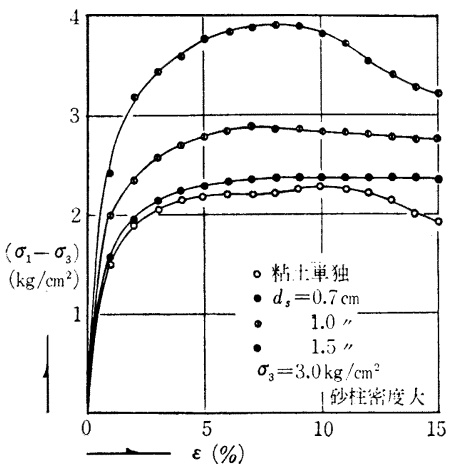

図-21 主応力差と鉛直ひずみの関係 $\left(K_{0}\right.$-test 後) 柱を含む粘土供試 体の等方圧密後の せん断試験におけ る $\left(\sigma_{1}-\sigma_{3}\right) \sim \varepsilon$ 関 係の一例である。 複合土の応力〜ひ ずみ曲線には砂柱 の影響が表われて いる。また最大主 応力差を含水比に 対して描いたの

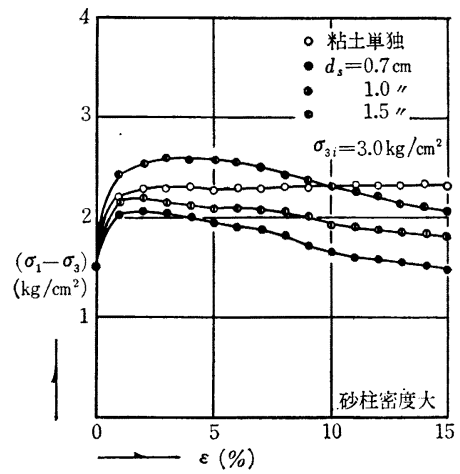


増加をみせていないが， $d_{s}=1.5 \mathrm{~cm}$ になると粘土単独 の場合の約 2 倍の強さを示している。しかも後の図一22 飞示すように複合土の場合, 試験終了後の粘土部の含水 比が粘土単独の場合とほぼ同等かそれ以上になっている ことに注意しておかなければならない。一方側方変位の ない圧密を受けた図一21 の場合においてもやはり $d_{s}$ の 増加につれて主応力差は大きくなっているが, その程度 は図一20の場合のように大きくなく，また $d_{s}=0.7$ お よび $1.0 \mathrm{~cm}$ の場合には粘土単独の場合よりもむしろ小 さくなっている。しかしこの場合も各供試体の粘土部の 含水比に注目して 評価することが重 要である。この意 味で以上 2 つの場 合に関して図一19 と同様の整理を行 なったのが図一 22, 図一23 であ る。データーは多 少ばらついてはい るが傾向は比較的 はっきりしてい る。すなわち, $d_{s}=0.7 \mathrm{~cm}$ の場 合には等方圧密 後, $K_{0}$-test 後の マずれの場合も砂 柱による強度増加 はほとんどみられ 打以が， $d_{s}=1.0$ $\mathrm{cm}$ になると前者 ではかなりの程 度，また後者でも ごくわずかではあ るがその効果があ らわれ， $d_{s}=1.5$

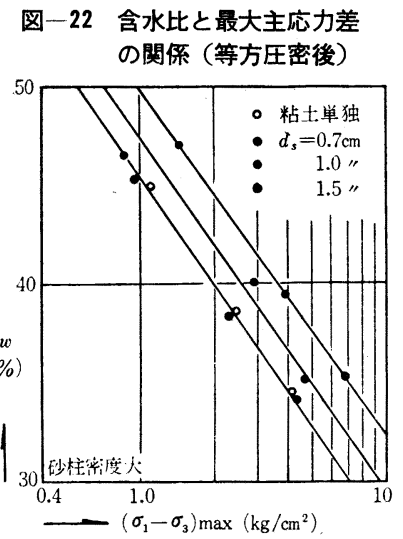

図一23 含水比と最大主応力差の関係 ( $K_{0}$-test 後)

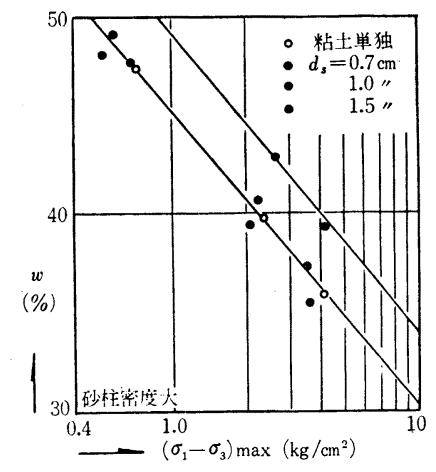

$\mathrm{cm}$ の場合には同一粘土部含水比に対し全般に著しい強 さ増加が認められる。なお三軸圧縮試験ではせん断中の 側方変位量がかなり大きいが，群ぐい状態で砂柱を含ん でいる実際の複合地盤の場合にはこの側方への変位がか なりの程度拘束され, 実際には三軸の場合の側圧に相当 する拘束力がせん断中に徐々に増大することが考えら れ, したがって一般に図-19, 図一22, 図一23 の結果 よりも砂柱効果が大になるのではないかと予想される。

図一24 は (B) に関し砂柱密度を変化させた場合の $\left(\sigma_{1}-\sigma_{3}\right) \sim \varepsilon$ 関係を描いた一例である。初期の砂柱密度 が小さい場合にはその強さは粘士単独の場合とほとんど 変わらない。砂柱密度が增すと強さはかなり上昇する
図-24 主応力差と鉛直ひずみの関係

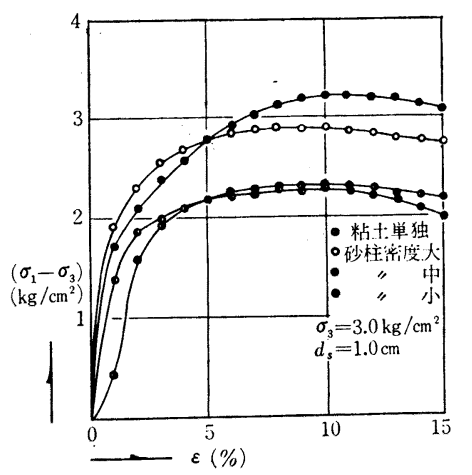

図一25 主応力差と鉛直ひずみの関係

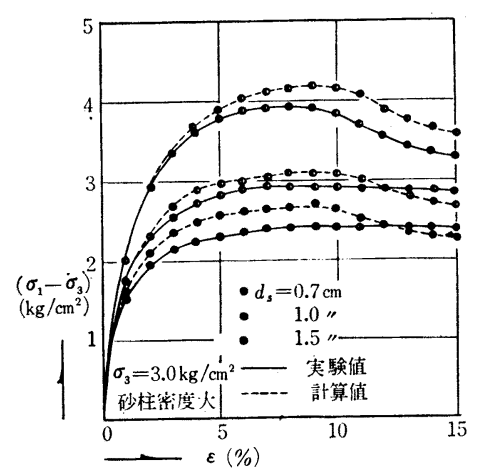

が, しかし 図一24 はこれにも限度が存在することを示 唆している。このことは注目しておかなければならない 事実であり, 非圧密非排水試験の場合の図一15 と同様 砂柱密度の上昇には粘土の強さとの関連において限度が あるものと予測される。

図一25 は図一17 の整理と同じように式 (17) を用い て計算した結果を実験結果と比較した一例であり，(B) に関して等方圧密したあとのものである。計算のもとと なる砂および粘土単独供試体の $\left(\sigma_{1}-\sigma_{3}\right) \sim \varepsilon$ 関倸はそれ ぞれ排水せん断（図一16）および圧密非排水試験より求 め, 計算には式 (17) 中の $a$ を 1 とした。このようにす ると図に示すように計算曲線は実験曲線と非常によく一 致し, しかも最大主応力差を与えるひずみ量にもほとん ど差がない。図は省略するが (A) に関しても両者は非 常によい一致を示した。このことは砂柱を含む複合土の 強さや変形の性質を推定するうえで非常に興味深いこと であるが，先にも述べたように厳密な意味では式 (17) 自身妥当性を欠いている面もあり，また $a$ の不明確さな どもあわせて今後の実験的研究により明らかにしていか なければならないと考えている。

つぎにせん断中の間げき水圧の挙動について述べる。 ここでは主として（B）に関する結果を検討する。図一 26 は等方圧密後の供試体のせん断中の砂柱部および粘 土部の間げき水圧を軸ひずみに対して描いた一例で, 
図一26間げき水圧と鉛直ひずみの関係

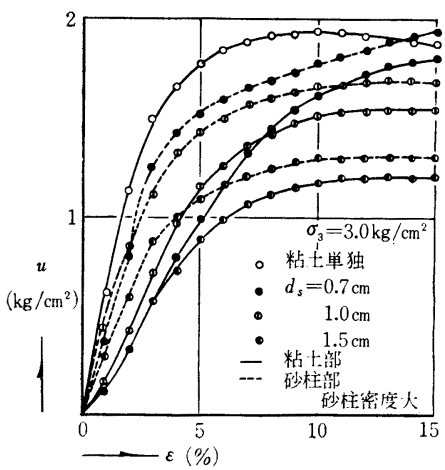

図一20 亿対応する結果である。この図によると複合土 では粘土単独供試体の場合にくらべて発生間げき水圧が 小さい。また $d_{s}$ の増大とともに間げき水圧が小さくな っているが，これは $d_{s}$ が大になるにしたがって供試体 全体に対する砂柱部のせん断の影響程度が大きくなって くるからであらう（試みに今回程度の密度を有する砂単 独供試体に関して等体積せん断をすると明らかに負圧を 発生する)。また砂単独供試体における間げき水圧の挙 動から予想すると一見砂柱部の間げき水圧は非常に低い かまたは負になるのではないかと予想されるが，これに 反して実際には図に示すように砂柱部の間げき水圧は全 般にかなり高く, しかも同時に測定された粘土部のそれ よりも大きくなっていることに注目しなければならな い。ここにも複合土の特殊性があり, 現象は非常に複雑 であるが, 砂中への圧力の集中という観点から砂柱部に 作用する平均圧力が粘土部のそれにくらべて予想以上に 大きいことに起因すると考えるのが自然であろう。一つ の試みとして粗雑ではあるが, せん断中の応力集中に関

$$
\begin{aligned}
\sigma_{s} & =\frac{3 \Delta u_{s}+\left(\sigma_{1}+2 \sigma_{3}\right)+3 \sqrt{2} a_{s}\left(\sigma_{1}-\sigma_{3}\right)}{\left(1+2 K_{1}\right)+3 \sqrt{2} a_{s}\left(1-K_{1}\right)} \\
\sigma_{c} & =\frac{3 \sqrt{2} \Delta u_{c}+\left(\sqrt{2}+6 a_{c}\right) \sigma_{1}+\left(\sqrt{2}-3 a_{c}\right) \sigma_{3}-\left(\sqrt{2}-3 a_{c}\right) K_{1} \sigma_{s}}{\sqrt{2}+6 a_{c}}
\end{aligned}
$$

ここに， $K_{1}=\sigma_{i} / \sigma_{s}$ で土圧係数のようなものである(村 山 ${ }^{21)}$ はコンポーザー打設地盤の強さに関して, 限界状態

におけるこの $K_{1} に, K_{1}=(1-\sin \phi) /(1+\sin \phi)$ を適用 している。この式によるとたとえば $\varphi=30^{\circ}, 40^{\circ}$ に対し

\section{図一27 $N=\sigma_{s} / \sigma_{c}$ と鉛直ひずみ} の関係

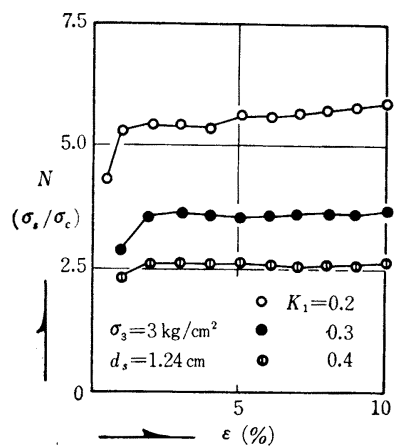

図一28間げき水圧と鉛直ひずみの関係

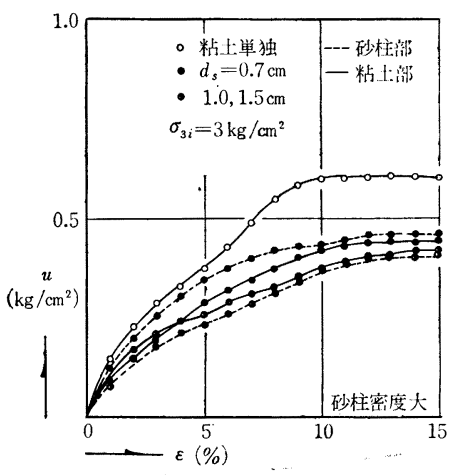

て $K_{1}=0.33,0.22$ となる)。さて図一26の $d_{s}=1.0 \mathrm{~cm}$ の場合に関して $K_{1}=0.2,0.3$, 0.4 として $\sigma_{s}, \sigma_{c}$ を計算し, $N\left(=\sigma_{s} / \sigma_{c}\right)$ を $\varepsilon$ に対して描いたのが 図一27 である。 図から上記のような計算によると鉛直圧力 の集中比がこの場合 $2.5 \sim 6$ 程度になるこ とがわかる。なお計算にあたり, 式 (22) 中の $a_{s}, a_{c}$ としては砂あるいは粘土単独 供試体による試験結果から算出した值を用 いた。

図一28 は $K_{0}$-test 後のせん断試験に関 するもので, 図一21 に対応するものであ 
る。図一28を図一27 と比較すると, 前者は後者にくら べて発生する間げき水圧の絶対量がはるかに小さい。こ れは図一28 の場合図一27 に比較して供試体の受ける全 体としての平均圧力が小さいのに加えて, 主応力差によ って発生するべき間げき水圧のかなりの量がすでに圧密 中に発生しているからである。また $d_{s}=1.0 \mathrm{~cm}$ 以上に なると図一27 の場合とは逆にわずかではあるが粘土部 の間げき水圧のほうが砂柱部のそれよりも高くなってい る。これらは砂柱部と粘土部の外圧分担割合に主として 支配されると考えられるが，いずれにしても複合土の粘 土部の間げき水圧は粘土単独の場合に比較してはるかに 小さいから，複合土には砂のダイレイタンシー効果と砂 柱への圧力集中の影響がはいっていることは事実であ る。以上の結果は $\sigma_{3 i}$ の大きさにかかわらず同傾向で あった。

\section{表一3 圧密非排水せん断試験結果}

\begin{tabular}{|c|c|c|c|c|c|c|}
\hline \multirow{2}{*}{ 試験番号 } & \multirow{2}{*}{$\begin{array}{c}d_{s} \\
(\mathrm{~cm})\end{array}$} & \multirow{2}{*}{$\begin{array}{l}\sigma_{3} \text { or } \sigma_{3 i} \\
\left(\mathrm{~kg} / \mathrm{cm}^{2}\right)\end{array}$} & \multirow{2}{*}{$\begin{array}{c}\left(\sigma_{1}-\sigma_{3}\right)_{\max } \\
\left(\mathrm{kg} / \mathrm{cm}^{2}\right)\end{array}$} & \multicolumn{2}{|c|}{$u \quad\left(\mathrm{~kg} / \mathrm{cm}^{2}\right)$} & \multirow{2}{*}{$\begin{array}{c}\phi \\
\left({ }^{\circ}\right)\end{array}$} \\
\hline & & & & 粘土部 & 砂中部 & \\
\hline A-10 & 0 & 1.0 & 1.22 & 0.61 & & \multirow{5}{*}{19} \\
\hline A-11 & 0 & 1.5 & 1.38 & 0.89 & & \\
\hline A-12 & 0 & 2.0 & 1.86 & 1.10 & & \\
\hline A-13 & 0 & 2.5 & 2.11 & 1.52 & & \\
\hline A-14 & 0 & 3.0 & 2.77 & 1.95 & & \\
\hline A-15 & 1.24 & 1.0 & 1.30 & 0.29 & & \multirow{7}{*}{22} \\
\hline A-16 & 1.24 & 1.5 & 1.92 & 0.40 & & \\
\hline A-17 & 1.24 & 1.5 & 1.74 & 0.62 & & \\
\hline A-18 & 1.24 & 1.5 & 1.71 & 0.55 & & \\
\hline A-19 & 1.24 & 1.5 & 1.74 & 0.51 & & \\
\hline$A-20$ & 1.24 & 2.5 & 3.43 & 0.71 & & \\
\hline$A-21$ & 1.24 & 3.0 & 3.57 & 0.50 & & \\
\hline B-19 & 0 & 1.0 & 1.10 & 0.21 & & \multirow{3}{*}{18} \\
\hline B-20 & 0 & 3.0 & 2.30 & 1.46 & & \\
\hline B-21 & 0 & 5.0 & 4.37 & 2.90 & & \\
\hline B-22 & 0.7 & 1.0 & 0.87 & 0.38 & 0.48 & \multirow{3}{*}{18} \\
\hline B-23 & 0.7 & 3.0 & 2.39 & 1.62 & 1.81 & \\
\hline B-24 & 0.7 & 5.0 & 4.08 & 2.64 & 2.86 & \\
\hline B-25 & 1.0 & 1.0 & 0.94 & 0.45 & 0.51 & \multirow{3}{*}{19} \\
\hline B-26 & 1.0 & 3.0 & 2.90 & 1.37 & 1.57 & \\
\hline B-27 & 1.0 & 5.0 & 4.61 & 2.30 & 2.68 & \\
\hline B-28 & 1.5 & 1.0 & 1.42 & 0.31 & 0.40 & \multirow{3}{*}{23} \\
\hline B-29 & 1.5 & 3.0 & 3.89 & 1.12 & 1.24 & \\
\hline B-30 & 1.5 & 5.0 & 6.65 & 1.80 & 2.10 & \\
\hline B-31 & 1.0 & 3.0 & 2.94 & 1.05 & 1.44 & \\
\hline B -32 & 1.0 & 3.0 & 2.37 & 1.01 & 1.40 & \\
\hline B-33 & 0 & 1.0 & 0.72 & 0.14 & & \multirow{3}{*}{17} \\
\hline B-34 & 0 & 3.0 & 2.35 & 0.60 & & \\
\hline B-35 & 0 & 5.0 & 4.08 & 0.50 & & \\
\hline B-36 & 0.7 & 1.0 & 0.58 & 0.10 & 0.03 & \multirow{3}{*}{15} \\
\hline B-37 & 0.7 & 3.0 & 2.06 & 0.09 & 0.13 & \\
\hline B-38 & 0.7 & 5.0 & 3.59 & 0.32 & 0.47 & \\
\hline B-39 & 1.0 & 1.0 & 0.52 & 0.14 & 0.05 & \multirow{3}{*}{15} \\
\hline B -40 & 1.0 & 3.0 & 2.20 & 0.13 & 0.16 & \\
\hline B-41 & 1.0 & 5.0 & 3.47 & 0.18 & 0.25 & \\
\hline B-42 & 1.5 & 1.0 & 0.68 & 0.10 & 0 & \multirow{3}{*}{17} \\
\hline B -43 & 1.5 & 3.0 & 2.62 & 0.22 & 0.32 & \\
\hline B-44 & 1.5 & 5.0 & 4.07 & 0.10 & 0.10 & \\
\hline
\end{tabular}

b）のせん断試験の結果は一括して表一3 に示してあ る。表中試験番号 A-10 B-30 は砂柱密度大 で等方圧 密後のせん断試験結果，B-31, B-32 も等方圧密後であ るが密度がそれぞれ中および小，B-33〜B-44 までは密 度大で一次元圧密後のせん断試験結果である。

c) 砂柱のみに鉛直付加荷重を加えた場合のせん断強 さ 粘土部にくらべて砂柱に極端に大きな鉛直荷重が 作用する場合が考えられる。このような状態下にある複 合土供試体の強さを調べるために，(B) に関して非圧 密あるいは圧密後非排水状態で砂柱のみに鉛直付加荷重 を加える試験を行なった。図一29 は試験結果の一例で あり, 点線は圧密しない供試体に, また実線は等方圧密 した供試体に関するものである。この図によると $d_{s}$ が 小なるほど, すなわち粘土部の厚さが大であるほど主応 力差は大きく, 特に等方圧密後の $d_{s}=0.7,1.0 \mathrm{~cm}$ の場 合の最大主応力差は砂単独供試体の場合（図一16）をは るかに上まわっている。また実線と点線を比較すると実 線のほうがはるかに大きい。これらのことはこの種の載 荷条件のもとでの強さが砂柱自身の強さに依存すると同 時に，砂柱を拘束する粘土の厚さと強さに大きく支配さ れることを示している。実線および点線に関して $d_{s}$ の 異なるそれぞれ 3 個ずつの供試体については, その粘土 部の強さにほとんど差がないと考えられるから， $d_{s}$ の 変化によるせん断強さの相違は砂柱を補捉している粘土 部の厚さに主として依存している。この意味でつぎのよ うな再整理をしてみることは有意義である。

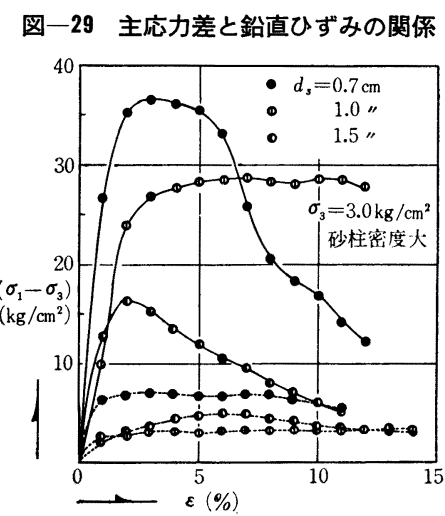

影響圈全体（供試体全体）として考えたとき，全断面 積に対して結局総計どれだけの載荷を許したことになる か, すなわち 1 つの単位の面積である影響圏全体に対し て評価したとき上述のせん断強さが面積的にみてどの程 度の有効さがあるかということは，このような載荷条件 が予測される場合の実際問題においては砂柱径を決定す る一つの重要な要素となる。このためには, 上述の主応力 差 $\left(\sigma_{1}-\sigma_{3}\right)$ を砂柱部の断面積 $A_{s}$ に乗じたもの,すなわち 影響圈全体の面積を占有しながら結局ささえうる力とし て砂柱の効果を評価すればよい。いま影響圈全体の断面 
積 $A_{t}$ はすべて同 じとして大差ない 加， $\left(\sigma_{1}-\sigma_{3}\right) A_{s}$ を $A_{t}$ で除した応 カで表示すること にして図一29を 整理しなおしたも のが図一30であ る。この図と粘土 単独供試体の場合 （たとえば図一
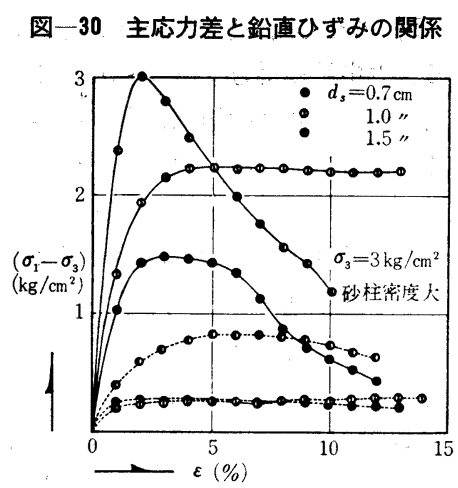

12, 図一20 参照)

を比較すればわかるように, $d_{s}=1.5 \mathrm{~cm}$ の場合の主応力 差は粘土単独のそれに比較してはるかに大きく砂柱打設 の意義が十分あるのに対して, $d_{s}=1.0 \mathrm{~cm}$ の場合は粘 土単独の場合を少し上まわる程度にすぎず，さらに $d_{s}$ $=0.7 \mathrm{~cm}$ の場合ではむしろこれより小さくなっている。 このことは砂柱に極端に大きな鉛直荷重が集中する場合 には, 影響圈全体に対する砂柱径にはおのずから有効な 大きさが存在することを示している。砂柱径があまりに 小さいと経済的な地盤面積の活用といら見地からはなは だ不利でありここような場合には砂柱部への鉛直荷重 の集中をできるだけ避ける手段をとるべきである。

表-4 に本節で述べた試験結果を総括してある。試験 番号 B-45 B-60 は圧密後砂柱に載荷した場合で B-58 までが初期密度大， B-59 が中，B-60 が小である。また

\section{表-4 砂柱のみに战荷した場合のせん断試験結果}

\begin{tabular}{|c|c|c|c|c|}
\hline 試験番号 & $\begin{array}{c}d_{s} \\
(\mathrm{~cm})\end{array}$ & $\begin{array}{c}\sigma_{3} \\
\left(\mathrm{~kg} / \mathrm{cm}^{2}\right)\end{array}$ & $\begin{array}{c}\left(\sigma_{1}-\sigma_{3}\right)_{\max } \\
\left(\mathrm{kg} / \mathrm{cm}^{2}\right)\end{array}$ & $\begin{array}{c}\left(\sigma_{1}-\sigma_{3}\right) \max \\
\times A_{s} / A_{t} \\
\left(\mathrm{~kg} / \mathrm{cm}^{2}\right)\end{array}$ \\
\hline B-45 & 0.7 & 1.0 & 12.62 & 0.51 \\
\hline B-46 & 0.7 & 3.0 & 36.53 & 1.47 \\
\hline$B-48$ & 0.7 & 3.0 & 43.76 & 1.75 \\
\hline B-49 & 0.7 & 5.0 & 49.92 & 2.00 \\
\hline B-50 & 0.7 & 5.0 & 43.16 & 1.73 \\
\hline B-51 & 1.0 & 1.0 & 8.79 & 0.72 \\
\hline B-52 & 1.0 & 3.0 & 28.97 & 2.36 \\
\hline B -53 & 1.0 & 5.0 & 39.80 & 3.25 \\
\hline B-54 & 1.5 & 1.0 & 6.40 & 1.18 \\
\hline B-56 & 1.5 & 1.0 & 6.87 & 1.26 \\
\hline B-57 & 1.5 & 3.0 & 16.34 & 3.01 \\
\hline B-58 & 1.5 & 5.0 & 23.44 & 4.31 \\
\hline B-59 & 1.0 & 3.0 & 27.00 & 2.21 \\
\hline B-60 & 1.0 & 3.0 & 25.70 & 2.10 \\
\hline B-61 & 0.7 & 1.0 & 7.46 & 0.30 \\
\hline B -62 & 0.7 & 3.0 & 7.05 & 0.28 \\
\hline B-63 & 0.7 & 5.0 & 9.50 & 0.38 \\
\hline B -64 & 1.0 & 1.0 & 4.41 & 0.36 \\
\hline B-67 & 1.0 & 3.0 & 3.78 & 0.31 \\
\hline B-68 & 1.0 & 5.0 & 4.68 & 0.38 \\
\hline B-69 & 1.5 & 1.0 & 2.76 & 0.51 \\
\hline B-70 & 1.5 & 3.0 & 4.53 & 0.84 \\
\hline B-71 & 1.5 & 5.0 & 3.08 & 0.57 \\
\hline B-72 & 1.0 & 3.0 & 3.47 & 0.28 \\
\hline B-73 & 1.0 & 3.0 & 3.37 & 0.28 \\
\hline
\end{tabular}

B-61〜B-73 の試験は非圧密の供試体に関するもので, B-71 までが密度大，B-72 が中，B-73 が密度小に関す る試験結果である。

\section{5. むす び}

粘性土中に砂柱を含む複合地盤の変形や強さに関する 種々の挙動は非常に複雑で, 未解明な点が多い。このよ らな複合地盤の力学的性質を解明するための第 1 段階と して, 砂柱を含む粘土供試体の圧密やせん断強さに関し て三軸圧縮試験による実験的研究を行ない, 種々の考察 を加えた。得られたおもな結果を列挙すると以下のとお りである。

（1）圧密促進におよぼす砂柱の効果は顕著であり, その圧密過程は圧密係数のとり方を誤まらないかぎり一 般に Barronの理論式によく一致するが, 合致の程度は $K_{0}$-test より:等方圧密のほうがよかった。

（2） $K_{0}$-test における過剩間げき水圧の消散過程は 等方圧密の場合にくらべて圧密初期においては早く, ま た圧密終期には逆に遅れてくる。

(3) 砂柱径が $1.0 \mathrm{~cm}(n=3.5)$ 以上になると沈下の 低減効果が顕著であった。また沈下量に関する考察より 砂柱部と粘土部に作用する鉛直圧力の比の試算式を示し た。

（4） $K_{0}$-test における主応力比は圧密の進行ととも に 1 から次第に減少し, 圧密終了時には 0.5 に漸近し た。

（5）砂柱を含む粘土の強さに関して, 二次元弾塑性 問題としての厚肉中空円筒の考え方を拡張, 適用するの は種々の現象面から考えて問題が多い。

（6）非圧密非排水せん断強さは $d_{s}$ が大であるほど， また側圧が大であるほど大きい。また砂柱の密度を増す とせん断強さは上昇するが, 粘土部の強さとの関連にお いて有効な充てん砂の密度には限界がある。

（7）上述した実験結果を式（17）で $a=1 / 2$ とした 計算結果と対比したところ両者はよく一致した。

（８）圧密非排水せん断強さに関しても（6）と同様 の傾向があったが，全般に $K_{0}$-test 後の場合にくらべて 等方圧密後の強さの増加がより顕著であった。また半対 数紙上に最大主応力差と粘土部の含水比の関倸を描くと 両者はほぼ直線関係にあり，せん断強さの増加の様子が 明らかとなった。

（9）等方圧密後のせん断強さに関して, 式 (17) の $a$ を 1 として計算した結果は実験結果と非常によく一致 した。

（10）等方圧密後の場合にくらべて $K_{0}$-test 後の供試 体ではせん断中に発生する過剩間げき水圧はかなり小さ く,また砂柱への鉛直圧力の集中に起因して砂柱部の間 げき水圧は予想以上に大きかった。間げき水圧に関する 
考察に基づいて圧力集中比の試算結果を示した。

（11）砂柱に極端に大きな鉛直載荷が行なわれる場 合, 複合土のせん断強さは粘土部の強さと厚さに支配さ れるが, 強さが同じ場合, 粘土部の厚さに関連して有効 な砂柱径の考え方を実験結果に基づいて示した。

終りにあたり終始ご指導を賜った京都大学村山朔郎教 授, 同赤井浩一教授, 同柴田徹助教授に対し深く感謝す るとともに，実験に協力された市川裕一氏（現大阪市） に感謝する次第である。また本研究が 40 年度文部省科 学研究費 (課題番号 5071) の補助のもとに実施された ことを記し謝意を表する。

\section{参考文 献}

1) Barron, R.A. : Consolidation of Fine-Grained Soils by Drain Wells, Trans. of Am. Soc. Civil Eng., Vol. 113, 1948, pp. 718 742.

2) Rendulic, L. : Der Hydrodynamische Spannungsausgleich in Zentral Entwasserten Tonzylindern, Wasserwirtschaft und Technik, Vol. 2, 1935, pp. 250 253, pp. $269 \sim 273$.

3) Richart, F.E., Jr. : A Review of the Theories for Sand Drains, Proc. of Am. Soc. Civil Eng., Jour. of Soil Mechanics and Foundation Div., Paper No. 1301, SM 3, 1957, pp. 1301-1 1301-38.

4) Schiffman, R.L. : Consolidation of Soil under TimeDependent Loading and Varying Permeability, Proc. of Highway Research Board, Vol. 37, 1958, pp. 584 617.

5) Terzaghi, K. : Erdbaumechanik, F. Deuticke, Vienna, 1925, pp. 111 183.

6）赤井浩一・足立紀尚：有効応力よりみた飽和粘土の一次 元圧密と強度特性に関する研究, 土木学会論文集, 第 113 号, 1965, pp. 11 27.

7）茨木竜雄・佐藤勝英：複合土の直接せん断試験による実 験的研究, 第 21 回土木学会年次学術講演会 講演概要第 III部, pp. 62-1 62-2.

8）茨木竜雄 : 複合土の直接せん断試験による実験的研究(第
1 報), 土と基礎, Vol. 13, No. 3, 1965, pp. 19 24.

9) Hill, R., Lee, EH. and Tupper, S.J. : Plastic Flow in a Closed Ended Tube with Internal Pressure, Proc. of 1st U.S. Nat. Cong. Appl. Mech. 1952, pp. $561 \sim 566$.

10) Steel, M.C. : Partially Plastic Thick-Walled Cylinder Theory, Jour. of Appl. Mech., Vol. 19, 1952, pp. 133 140.

11) Hodge, P.G., White. G.N., Jr. and Providence, R.I. : A Quantitative Comparison of Flow and Deformation Theories of Plasticity, Jour. of Appl. Mech, Vol. 17, 1950, pp. $180 \sim 184$.

12) 前出 5), pp. $211 \sim 222$.

13) Terzaghi, K. : Theoretical Soil Mechanics, John Wiley and Sons Inc., 1943, pp. 202 215.

14) Fröhlich, O.K. : Druckverteilung im Baugrunde, Tulius Springer, 1934, pp. 166 177.

15) Wu, T.H., Loh, A.K. and Malvern, L.E. : Study of Failure Envelope of Solis, Proc. of Am. Soc. Civil Eng., Jour. of Soil Mechanics and Foundation Div., Paper No. 3430, 1963, pp. 145 181.

16) Timoshenko, S. and Goodier, J.M. : Theory of Elasticity, McGraw-Hill Book Co. Inc., 1951, pp. 1 28.

17) Hill, R. : The Mathematical Theory of Plasticity, Oxford Press, 1950, pp. 106 114.

18) Hythornthwaite, R.M. : Mechanics of the Triaxial Test for Soil, Proc. of Am. Soc. Civil Eng., Jour. of Soil Mechanics and Foundation Div., Paper No. 2625, SM 5, 1960, pp. 35 62.

19) Leonards, G. : Foundation Engineering, McGrawHill Book Co. Inc., 1962, pp. 176 179.

20) Henkel, D.J. : The Shear Strength of Saturated Remoulded Clays, Am. Soc. Civil Eng. Research Conf. on Shear Strength of Cohesive Soils, 1960, pp. 550 552.

21）村山朔郎：粘性土に対するヴァイブロ・コンポーザ工法 の考察, 建設の機械化, 第 150 号, 1962, pp. 10 15. 